\title{
Easternmost Locality Record and Morphological Data of Cyrtopodion scabrum (Heyden, 1827) (Squamata: Gekkonidae) in southeastern Anatolia, Turkey
}

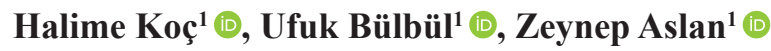

${ }^{1}$ Karadeniz Technical University, Faculty of Science, Department of Biology,

Trabzon, Turkey

ORCID: H.K. 0000-0003-2998-4384;

U.B. 0000-0001-6691-6968;

Z.A. 0000-0002-7340-7587

Received: 17.07.2019

Revision Requested: 12.08.2019

Last Revision Received: 20.10.2019

Accepted: 26.11.2019

Correspondence: Ufuk Bülbül

ufukb@ktu.edu.tr

Citation: Koç, H., Bülbül, U. \& Aslan, Z. (2020). Easternmost Locality Record and Morphological Data of Cyrtopodion scabrum (Heyden, 1827) (Squamata: Gekkonidae) in southeastern Anatolia, Turkey. Turkish Journal of Bioscience and Collections, 4(1), 1-6.

https://doi.org/10.26650/tjbc.20200033

\begin{abstract}
The locality record of the Rough Bent-toed Gecko (Cyrtopodion scabrum) from the Silopi District of the Şırnak Province of Turkey was provided in the present study. The new locality record extended the distribution area of the species $40 \mathrm{~km}$ to the east. Data based on meristic pholidosis characters, metric measurements and color-patter features of the specimens from Silopi were given in detail and compared with data given in the previous literature.
\end{abstract}

Keywords: Rough Bent-toed Gecko, Pholidosis, Morphometric, Silopi, New locality

\section{Introduction}

Rough Bent-toed Gecko, Cyrtopodion scabrum (Heyden, 1827) is a widely distributed species of the Cyrtopodion genus, ranging from the African coast side of the Red Sea, through the Arabian Peninsula, Iraq, Syria, Jordan, Israel, southeastern Turkey, Iran, Azerbaijan, Afghanistan, Pakistan and localities in the Rajasthan Desert, and India (Leviton et al., 1992; Dadashi et al., 2009; Uetz et al., 2013; Mohammed et al., 2015). It was also introduced in Texas, United States of America (Werner et al., 2010). It has been classified as LC (Least Concern) in the IUCN Red List since 2008 (Werner et al., 2010).

Baran and Gruber (1982) aimed to clarify the relationship degrees of the species belonging to the family Gekkonidae in
Turkey and they described the species, Cyrtodactylus basoglui. However, Cyrtodactylus basoglui was considered conspecific with Cyrtopodion scabrum. Cyrtodactylus basoglui is a synonym of Cyrtopodion scabrum (Werner et al., 2010).

In Turkey, C. scabrum was recorded from Şanliurfa (in the Harran, Siverek, Suruç, and Ceylanpınar districts), Mardin (in the Midyat and Nusaybin districts) and Şırnak (in the Cizre district) provinces (Baran \& Gruber, 1982; Baran \& Atatür, 1998; Sindaco et al., 2000; Cihan et al., 2003; Uğurtaş et al., 2007; Baran et al., 2013). Recently, the species has been reported from the Akçakale district in the Şanlıurfa Province (Çakmak, 2018).

The present study provides the easternmost locality record of Cyrtopodion scabrum in Turkey (Fig. 1) and all 
pholidolial and other morphological characteristics belonging to two adult female individuals of the species are presented.

\section{Material and Methods}

Material: KZL-347/2019, 2 우, 04.26.2019, Cumhuriyet, Silopi, Şırnak, leg. U. BÜLBÜL, and Z. ASLAN. During a field study on $26^{\text {th }}$ April 2019, 2 우 (The gekkonid lizards were sexed by sounding for the presence or absence of hemipenis pockets) individuals of Crytopodion scabrum were recorded from the Cumhuriyet Neighborhood, Silopi District of Şırnak Province $\left(37^{\circ} 25^{\prime} 454^{\prime \prime} \mathrm{N}, 42^{\circ} 25^{\prime} 585^{\prime \prime} \mathrm{E}, 965 \mathrm{~m}\right.$ a.s.1.).

The gekkonid lizards were caught on the walls of a garden around a house (Fig. 2). The garden consisted of mulberry, fig and vine trees. Because of their accidental discovery, we observed a small number of lizards. After the individuals were photographed in their natural habitat, they were anesthetized with MS 222. Then, 10\% formaldehyde was injected to the specimens and they were stored in $70 \%$ ethanol. The collection number (KZL-347 for Silopi) was given to the specimens and they were placed at the Karadeniz Technical University, Biology Department, Zoology Research Laboratory.

We prepared the metric and meristic data, modifying the data obtained from the studies of Rastegar-Pouyani et al. (2010) and Çakmak (2018). We used a stereomicroscope to observe the morphological characters and a digital caliper to measure the morphometric characters to the nearest $0.01 \mathrm{~mm}$. We obtained pholidolial features: supralabial scales (SL, left-right, posterior end defined by the last enlarged scale that touches infralabials at rear corner of mouth); infralabials (IL, left-right, posterior end defined by the posteriormost enlarged scales that contact the supralabials at the rear corner of the mouth); interorbital scales (IS, the number of scales between the eyes in the widest region); smooth scales across widest part of the belly (WB, number of scale rows around the trunk at midbody); trihedral tubercles of the dorsum (TTD, the number of trihedral tubercles across the widest part of the dorsum); trihedral tubercles (TT, the number

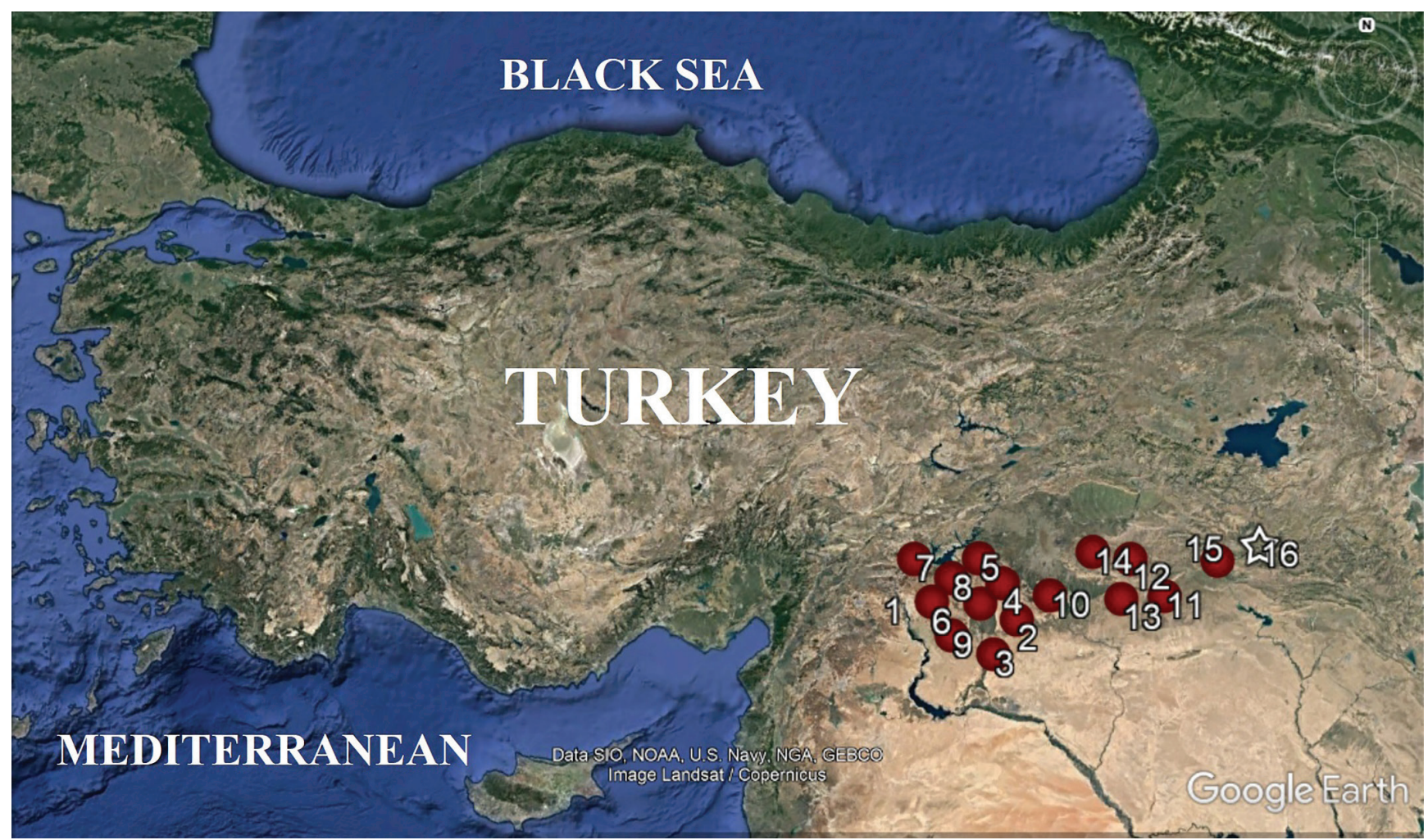

Figure 1. Map showing the localities of Cyrtopodion scabrum in Turkey. 1. Şeyh Maksut Neighborhood, Şanlıurfa 2. Şuayip District, Harran, Şanlıurfa 3. Koyunluca Village, Harran, Şanlıurfa 4. Tepedibi Village, Tektek Mountains, Şanlıurfa 5. Osmanbey Campus, Şanlıurfa 6. Akşemsettin Neighborhood, Şanlıurfa 7. Devteşti Neighborhood, Süleymaniye, Şanlıurfa 8. Osmanlı Neighborhood, Eyyübiye, Şanlıurfa 9. Sınırgören, Akçakale, Şanlıurfa 10. Ceylanpınar, Şanlıurfa; Suruç, Şanlıurfa, 11. Akçatarla, Nusaybin, Mardin 12. Nusaybin, Mardin 13. Kızıltepe, Mardin 14. Mardin 15. Cizre, Şırnak 16. Cumhuriyet Neighborhood, Silopi, Şırnak. The white colored star shows the new locality (Data from: Baran \& Gruber, 1982; Baran \& Atatür, 1998; Sindaco et al., 2000; Cihan et al., 2003; Uğurtaş et al., 2007; Baran et al., 2013; Çakmak, 2018). 
of trihedral tubercles from behind the neck to a point just above the vent); subdigital lamellae under the $4^{\text {th }}$ toe (SDL, left-right, number of 4th toe lamellae, from 1st lamella at the digit's cleft to the most distal lamella); transversal tubercles (TTMB, the number of transverse tubercles from the midbody); ventral scales (VEN, number of scales from below mental to the anterior border of the cloaca); number of the scales surrounding the nasal (SN, left-right, the scales surrounding the nasal, the number of the scales contacted by the rostral and supralabial); number of the scales between the nasal and eye (NE, left-right the number scales counted straight from the second nasal plate to the anterior part of the eye; number of the scales between the eye and tympanum (ET, left-right, the number of scales between the posterior part of the left eye and the anterior part of the tympanum opening, in the lateral part of the head); number of scales between upper labials (UL, the number of scales in single, between third upper labials); number of longitudinal dorsal tubercles (LDT, the longitudinal number of the dorsal tubercles); number of the surrounding dorsal tubercles (RDT, the mean number of scales around the five tubercles randomly selected from the dorsal); gularia (GLR, the number of the scales starting from the scales contacting the mental to the level of the posterior of the tympanum opening, in the ventral part of the head); number of the cloacal spines (CS, the spines lined symmetrically on both sides of the tail near the cloaca); number of the scales surrounding the postmental (SP, the number of the scales in contact with the postmentals).

The morphometric measurements in this study following: snout-vent length (SVL, from tip of snout to the anterior border of the cloaca); tail length (TL, from the posterior border of the cloacal opening to tip of tail); head width (HW, distance from left to right outer edge of the head at its widest point); head length (HL, from snout tip to the posterior border of tympanum); head depth (HD, dorsoventral distance from the top of head to the underside of the jaw at the transverse plane intersecting the angle of the jaws); fore limb length (FLL, from

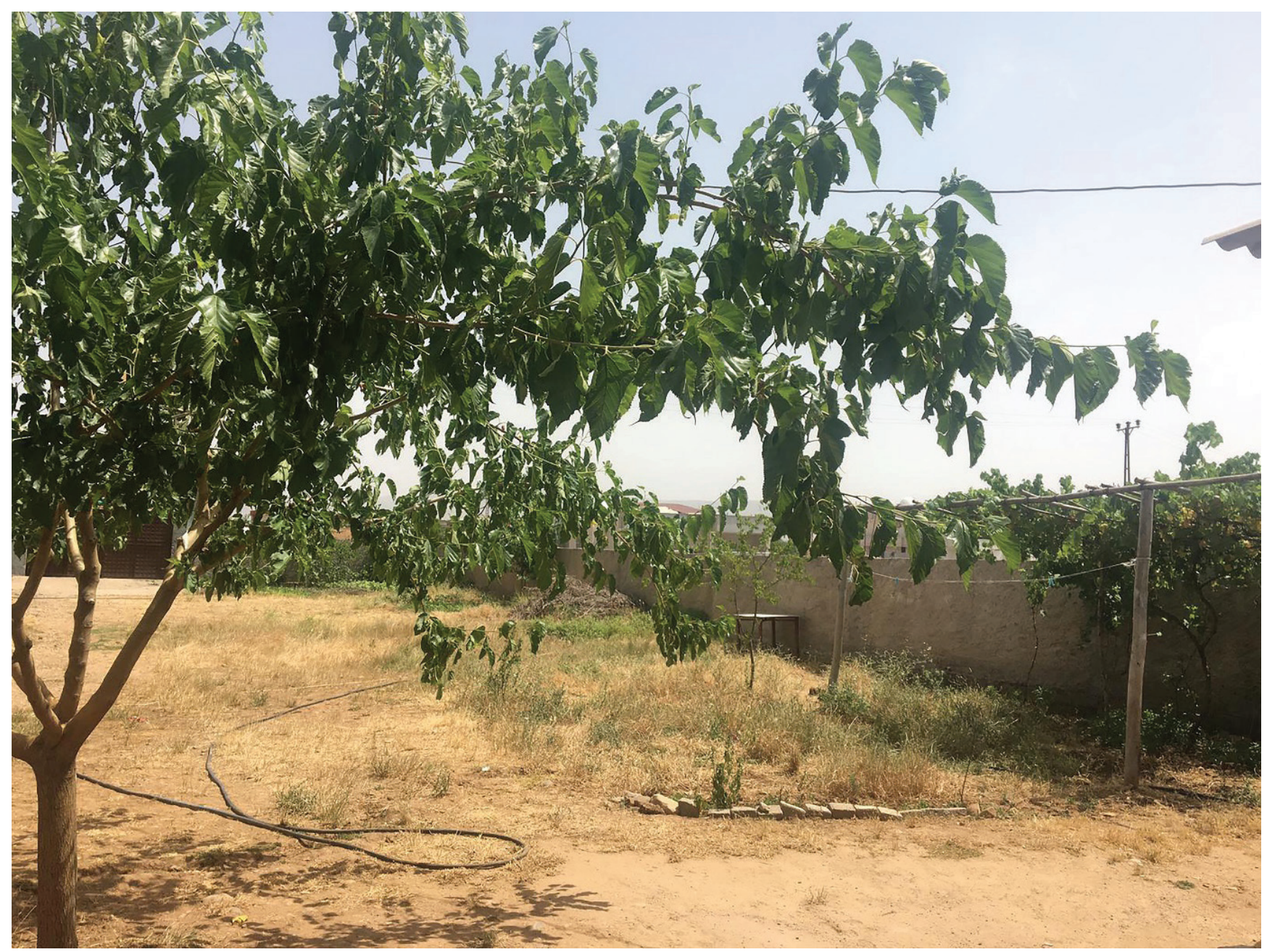

Figure 2. A general view of the habitat of Cyrtopodion scabrum from Cumhuriyet, Silopi, Şrnak (Photo by Zeynep ASLAN). 
shoulder joint to tip of fourth toe); hind limb length (HLL, from groin to tip of fourth toe), snout-eye length (SEL, from snout tip to the anterior border of the eye); eyetympanum length (ETL, from the posterior border of the eye to the anterior border of tympanum); horizontal eye diameter (HEYED, the greatest diameter of horizontal eye); vertical eye diameter (VEYED, the greatest diameter of the vertical eye); horizontal ear diameter (HEARD, the greatest diameter of the horizontal tympanum) and the vertical ear diameter (VEARD, the greatest diameter of the vertical tympanum).

\section{Results}

We caught two adult female individuals between 4 and 5 p.m. on $26^{\text {th }}$ April 2019. The temperature was about $17^{\circ} \mathrm{C}$.

Pholidolial characteristics: The number of supralabial scales (left-right) was 10-10 in both specimens. 9-8 (leftright) infralabial scales were counted in both specimens. The number of lamellae under the $4^{\text {th }}$ toe was 26-24 (leftright) in the first female specimen while it was 24-24 in the second one. The longitudinal tubercles on the dorsum were small and keeled. The number of scales (left-right) between the posterior part of the left eye and the anterior part of the ear opening, in the lateral part of the head was 18-18 in the first female specimen while it was 24-24 in the second one. The number of scales in contact with the postmentals was 10 in both specimens. The scales (left-right) surrounding the nasal, the scales contacted by rostral and supralabial was 1-1 in both specimens. The mean number of scales around the five tubercles randomly selected from the dorsal was 10.8 in the first female specimen while it was 9.6 in the second one.

Morphometric measurements: SVL was $36.68 \mathrm{~mm}$ and $34.38 \mathrm{~mm}$ for the first and second female individuals, respectively. Tail length was $88.33 \mathrm{~mm}$ and $80.05 \mathrm{~mm}$, respectively. Head wide was $8.17 \mathrm{~mm}$ and $7.67 \mathrm{~mm}$, respectively. Head length was respectively $13.33 \mathrm{~mm}$ and $11.07 \mathrm{~mm}$, respectively. Horizontal eye diameter (leftright) was 2.70-2.73 in the first female specimen while it was 2.62-2.64 in the second one. Vertical ear diameter (left-right) was 1.36-1.33 in the first female specimen while it was 1.19-1.17 in the second one. The distance between the nostril and eye (left-right) was 3.12-3.74 in the first female specimen while it was 3.08-3.62 in the second one.

The metric and meristic characteristics of the collected specimens are given in Table 1.
Color-pattern: In the specimens of C. scabrum, the color of the back side was usually whitish. There were dark brown spots on the dorsum of the first female while these spots were light brown in the second female. The tubercles on the dorsal were white, brown and cream colors while they were white and brown colors in the second female. The ventral color was usually cream and white in both specimens. Dark brown colored bandings were observed in the tail of both specimens. The tubercles on the tail were white and light brown and the lower side of the tail had a white color in both specimens (Fig. 3).

Up to now the species has been reported from Şanlıurfa, Mardin and Şırnak (from the Cizre District) provinces of Turkey (Baran \& Gruber, 1982; Baran \& Atatür, 1998; Sindaco et al., 2000; Cihan et al., 2003; Uğurtaş et al., 2007). In the present study, we reported the easternmost locality record of C. scabrum in Turkey. The findings of the present study indicate that the individuals of the species can be found in other provinces having suitable habitats in the Southeastern Anatolian region of Turkey.

Diagnostic characteristics of the species: longitudinal concavity in the frontal region of the head, usually 30 scales between the centers of the eyes, pupil vertical with anterior and posterior margins, two or three pairs of postmental shields, the first pair usually in contact behind the mental, clawed and slender digits, three or more rows (generally) of lateral scales on digits, a single series of smooth transverse subdigital lamellae, end of digit weakly or not at all laterally compressed, no fringes or denticulations on the lateral digital scales, distal two or three phalanges make an angle with the proximal portion of the digits and males with preanal and/or femoral pores; segmentation of tail pronounced (Leviton et al., 1992).

Morphological and morphometric data belonged to the specimens of Silopi were compared to those of the samples of C. scabrum observed in the studies of Anderson \& Leviton (1969); Haas \& Werner (1969); Baran \& Gruber (1982); Rösler \& Glaw (2009); RastegarPouyani et al. (2010); Nazarov et al. (2011); Nazarov et al. (2012); Mohammed et al. (2015a); Mohammed et al. (2015b) and Çakmak (2018).

The numbers of SL, IL and TTMB were higher and the number of VEN was lower in the samples of Baran \& Gruber (1982) when compared our data. The morphological and morphometric data belonged to the specimens from the Southeastern Anatolia populations in the study of Çakmak (2018) were also compared to our samples. RDT appeared lower while TL was higher in our two specimens. TT and UL were lower in only 
one sample of the Silopi population. In addition, TL appeared higher while SEL and ETL were lower in our samples than in the specimens of Rösler \& Glaw (2009). When we compared our data to the specimen of Rastegar-Pouyani et al. (2010), the different

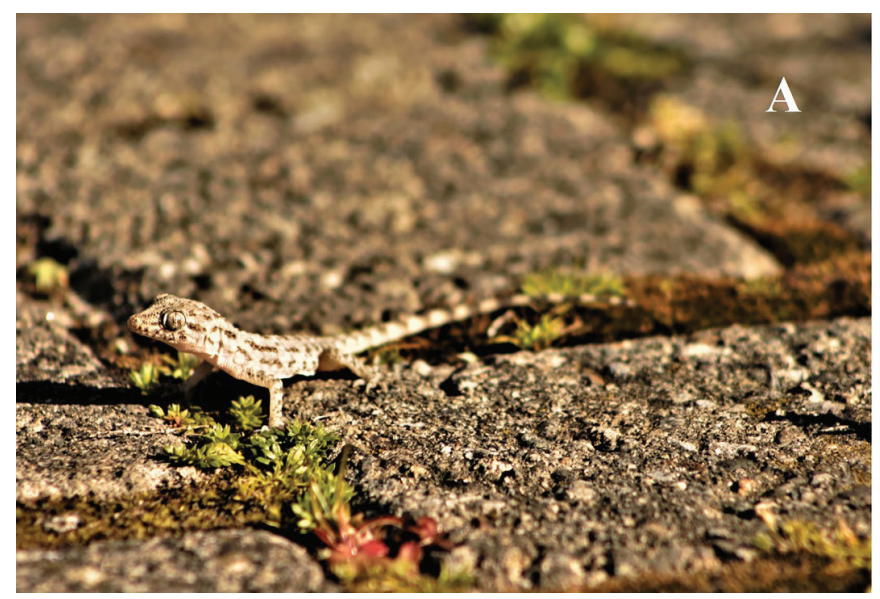

characteristics were only SDL (lower in Rastegar-

Pouyani et al. 2010) and TTD (lower in one specimen of Silopi). TL was higher in the Silopi population than in those of the samples of C. scabrum observed in the studies of Nazarov et al. (2011); Nazarov et al. (2012);

Figure 3. Two female specimens of Cyrtopodion scabrum in the studied population. A. The first female specimen, B. The second female specimen (Photo by Halime KOÇ).

Table 1. Descriptive statistics of some pholidolial characteristics and morphometric measurements of Cyrtopodion scabrum specimens collected from Silopi-Şırnak. L represents left and R represents right. For abbreviations see text.

\begin{tabular}{|c|c|c|c|c|c|}
\hline \multirow{2}{*}{ Character } & \multirow{2}{*}{$\begin{array}{c}\text { Rastegar-Pouyani et al. (2010) } \\
1 \text { adult } 0^{\lambda} 0^{\lambda}\end{array}$} & \multicolumn{2}{|c|}{ Çakmak (2018) } & \multicolumn{2}{|c|}{ This study } \\
\hline & & $27 \delta^{\top} \sigma^{\pi}$ (min-max) & 30 ९ (min-max) & $1^{\text {st }}+9$ & $2^{\text {nd }} \varphi Q$ \\
\hline SL (L-R) & $9-9$ & $9-11 ; 9-11$ & $8-11 ; 9-11$ & $10-10$ & $10-10$ \\
\hline IL (L-R) & $9-9$ & $7-9 ; 7-9$ & $7-10 ; 7-10$ & $9-9$ & $8-8$ \\
\hline IS & 15 & $9-15$ & $9-15$ & 16 & 15 \\
\hline WB & $20-21$ & - & - & 21 & 20 \\
\hline TTD & $13-14$ & - & - & 14 & 13 \\
\hline $\mathrm{TT}$ & $28-29$ & - & - & 28 & 26 \\
\hline SDL (L-R) & $20-21$ & $22-25 ; 22-26$ & $22-26 ; 22-28$ & $26-24$ & $24-24$ \\
\hline TTMB & - & $10-11$ & $9-11$ & 12 & 12 \\
\hline VEN & - & $16-21$ & $14-24$ & 24 & 23 \\
\hline SN (L-R) & - & $5-5$ & $5-5$ & $5-5$ & $5-5$ \\
\hline NE (L-R) & - & $10-16 ; 10-14$ & $10-14 ; 9-15$ & $12-12$ & $12-12$ \\
\hline ET (L-R) & - & $15-20 ; 15-21$ & $14-23 ; 15-23$ & $18-18$ & $18-17$ \\
\hline UL & - & $14-19$ & $14-19$ & 14 & 13 \\
\hline LDT & - & $10-11$ & $9-11$ & 12 & 11 \\
\hline RDT & - & $13-16$ & $12.5-17$ & 10,8 & 9,6 \\
\hline GLR & - & $34-45$ & $33-43$ & 38 & 38 \\
\hline CS & - & $1-2$ & $1-2$ & 1 & 1 \\
\hline SP & - & $9-16$ & $9-16$ & 10 & 10 \\
\hline SVL (mm) & 44.6 & $31-51$ & $31-55$ & 36.68 & 34.38 \\
\hline $\mathrm{TL}(\mathrm{mm})$ & - & $38-65$ & $37-71$ & 88.33 & 80.05 \\
\hline $\mathrm{HW}(\mathrm{mm})$ & 8.2 & $6.45-9.72$ & $5.49-11.62$ & 8.17 & 7.67 \\
\hline $\mathrm{HL}(\mathrm{mm})$ & 11.4 & $8.74-14.72$ & $8.49-14.68$ & 13.33 & 11.07 \\
\hline $\mathrm{HD}(\mathrm{mm})$ & 6.5 & $3.57-7.23$ & $3.38-7.96$ & 6.09 & 5.11 \\
\hline FLL (mm) & 21.3 & - & - & 21.04 & 20.02 \\
\hline HLL (mm) & 28.4 & - & - & 28.11 & 27.03 \\
\hline SEL (L-R) (mm) & - & $2.44-4.6 ; 2.96-4.52$ & $2.57-4.54 ; 2.86-5.16$ & $3.12-3.74$ & $3.08-3.62$ \\
\hline $\operatorname{ETL}(\mathrm{L}-\mathrm{R})(\mathrm{mm})$ & - & $2.8-4.51 ; 2.74-4.57$ & $2.79-4.98 ; 2.54-4.95$ & $3.98-3.96$ & $3.20-3.17$ \\
\hline HEYED (L-R) (mm) & - & $2.26-3.76 ; 2.46-3.69$ & $2.22-3.61 ; 2.28-3.82$ & $2.70-2.73$ & $2.62-2.64$ \\
\hline VEYED (L-R) (mm) & - & $1.53-3.09 ; 2.09-3.06$ & $1.98-3.36 ; 1.4-3.35$ & $2.04-2.02$ & $1.98-1.96$ \\
\hline HEARD (L-R) (mm) & - & $0.18-1.7 ; 0.17-1.72$ & $0.25-1.94: 0.18-1.7$ & $0.64-0.62$ & $0.59-0.57$ \\
\hline VEARD (L-R) (mm) & - & $0.34-1.38 ; 0.42-2.03$ & $0.5-2.18 ; 0.36-2.09$ & $1.36-1.33$ & $1.19-1.17$ \\
\hline
\end{tabular}


Mohammed et al. (2015a); Mohammed et al. (2015b). Finally, our data appeared similar to those of the samples observed in the studies of Anderson \& Leviton (1969) and Haas \& Werner (1969).

We used a very low number of the specimens. Comprehensive observations, including more individuals are necessary to compare the Silopi population with other Anatolian populations. Future detailed surveys from Silopi to the east and north may reveal the new localities of the species in the Southeastern Anatolian region of Turkey.

Peer-review: Externally peer-reviewed.

Author Contributions: Conception/Design of study: H.K., U.B., Z.A.; Data Acquisition: H.K., U.B., Z.A.; Data Analysis/Interpretation: H.K., U.B., Z.A.; Drafting Manuscript: H.K., U.B., Z.A.; Critical Revision of Manuscript: H.K., U.B., Z.A.; Final Approval and Accountability: H.K., U.B., Z.A.

Conflict of Interest: The authors declare that they have no conflicts of interest.

Financial Disclosure: There are no funders to report for this submission.

Acknowledgements: The authors wish to thank Aziz Aslan for his helping in the field.

\section{References}

Anderson, S., \& Leviton, A. E. (1969). Amphibians and reptiles collected by the Street Expedition to Afghanistan, 1965. Proceedings of the California Academy of Sciences, 37(2), 25-56.

Baran, İ., \& Gruber, U. (1982). Taxonomische unterschungen an Turkischen Gekkoniden. Spixiana, 5, 109-138.

Baran, İ., \& Atatür, M. K. (1998). Türkiye herpetofaunas1 (Amphibiler ve Sürüngenler). Ankara: Türkiye Cumhuriyeti Çevre Bakanlığı. ISBN: 975-7347-37-X.

Baran, İ., Ilgaz, Ç., Avc1, A., Kumlutaş, Y., \& Olgun, K. (2013). Türkiye amfibi ve sürüngenleri. Ankara: TÜBİTAK Popüler Bilim Kitapları. ISBN: 978-975-403-703-6.

Cihan, D., Tok, C. V., Tosunoğlu, M., Afsar, M., \& Ayaz, D. (2003). Mardin (Türkiye) civarından toplanan amfibiler ve reptiller hakkında. Anadolu Üniversitesi Bilim ve Teknoloji Dergisi, 4(2), 283-286.

Çakmak, Ş. (2018). Doğu ve Güneydoğu Anadolu Bölgesi'ndeki bazı illerin Gekkonidae faunası. Adıyaman University, Graduate School of Natural and Applied Sciences, Msc. Thesis.

Dadashi, E., Kami, H. G., \& Shaji'ee, H. (2009). The first report on keeled-rock gecko (Reptiles: Sauria: Gekkonidae) in East Azerbaijan Province. Journal of Animal Biology, 2(1), 33-39.
Haas, G., \& Werner, Y. L. (1969). Lizards and snakes from Southwestern Asia, collected by Henry Field. Bulletin of the Museum of Comparative Zoology at Harvard College, 138, 327-406.

Leviton, A. E., Anderson, S. C., Adler, K. A., \& Minton, S. A. (1992). Handbook to Middle East Amphibians andReptiles. (Ohio, USA): Oxford. ISBN: 0916984230.

Mohammed, R. H., Rastegar-Pouyani, N., Karamiani, R., \& Rhadi, F. A. (2015a). The lizard fauna of Al-Najaf province, Southern Iraq. Cumhuriyet University Faculty of Science Science Journal, 36(3), 21-30.

Mohammed, R. H., Rastegar-Pouyani, N., Karamiani, R., \& Rhadi, F. A. (2015b). Systematics and distribution of geckos in Iraq, systematics and distribution of the Gekkonidae in some provinces of Central and Southern Iraq. Indian Journal of Natural Sciences, 30(5), 7338-7345.

Nazarov, R. A., Ananjeva, N. B., \& Papenfuss, T. J. (2011). A new species of Thin-Toed Geckos Cyrtopodion sensu lato (Squamata: Sauria: Gekkonidae) from Balochistan Province, South Pakistan. Russian Journal of Herpetology, 18(2), 130-137.

Nazarov, R. A., Bondarenko, D. A., \& Radjabizadeh, M. (2012). A new species of Thin-Toed Geckos Cyrtopodion sensu lato (Squamata: Sauria: Gekkonidae) from Hormozgan Province, South Iran. Russian Journal of Herpetology, 19(4), 292-298.

Rastegar-Pouyani, N., Khosravani, A., \& Oraie, H. (2010). A new record of Cyrtopodion scabrum (Heyden, 1827) from the Caspian Sea Coastal Region, Guilan Province, Northern Iran. Herpetology Notes, 3, 61-63.

Rösler, H., \& Glaw, F. (2009). Morphologische variation von Cyrtopodion kachhense (Stoliczka, 1872), C. scabrum (Heyden, 1827) und C. watsoni (Murray, 1892) (Reptilia: Sauria: Gekkonidae) aus Belutschistan (Pakistan). Sauria, 30(4), 11-18.

Sindaco, R., Venchi, A., Carpaneto, G. M., \& Bologna, M. A. (2000). The reptiles of Anatolia: a checklist and zoogeographical analysis. Biogeographia, 21, 441-554.

Uetz, P., Freed, P., \& Hošek, J. (2013). The Reptile Database, URL: http://www.reptile-database.org (accessed 06.15.19).

Uğurtaş, İ. H., Yıldırım, H. S., \& Sevinç, M. (2007). Distribution of the Gekkonidae species in Southeast Anatolia, Turkey, and new localities. Turkish Journal of Zoology, 31, 137-141.

Werner, Y., Mousa-Disi, A. M., Tok, V., Ugurtas, I., Sevinç, M., Baha El Din, S. \& Nilson, G. (2010). Cyrtopodion scabrum. The IUCN Red List of Threatened Species 2010: e. T164748A5922551. http://dx.doi.org/10.2305/IUCN. UK.2010-4.RLTS.T164748A5922551.en. Downloaded on 12 December 2019. 